\title{
Studi Politik Ekonomi Dalam Permulaan Wacana Development
}

\author{
Oleh: Andi Dody M. Putra Agustang ; Andi Agustang \\ andidody@unm.ac.id, andi.agustang@unm.ac.id
}

Abstrak

Teori development dan modernisasi yang kini menjadi the mainstream teori dan praktek perubahan sosial di Indonesia, belum dapat menciptakan dunia yang secara mendasar lebih baik dan lebih adil (Andi Agustang)

\section{Pendahuluan}

Tulisan ini mencoba mengurai hasil penyelidikan penulis secara kritis terhadap gagasan 'development', yang menjadi sumber wacana 'pembangunan' di Indoneisa. Karena itu, perhatian uraian bukan dari segi bahasa, melainkan mencoba menstudi politik ekonomi dalam permulaan wacana development, dan bagaimana development disebar-serapkan kedunia ketiga, serta hubungannya dengan wacana 'pembangunan' di Indonesia sejak pemerintahan militer Orde baru.

Developmentalisme jelas dikembangkan dalam rangka membendung pengaruh dan semangat anti Kapitalisme bagi berjuta rakyat di Dunia Ketiga. Gagasan development dimulai tahun 1940an, khususnya pada tanggal 20 Januari 1949 saat President Amerika Harry S.Truman mengumumkan kebijakan pemerintahnya, maka istilah development dan "underdevelopment" resmi menjadi doktrin kebijakan luar negeri AS. Selain dimaksud memberi jawaban atas penolakan bangsa Dunia Ketiga yang baru merdeka atas kapitalisme, juga sebagai jawaban ideologi terhadap meningkatnya daya tarik rakyat Dunia Ketiga terhadap keberhasilan Uni Sovyet sebagai kekuatan baru ketika itu. Karena itu jelas gagasan development mulanya dilontarkan dalam kerangka 'perang dingin' untuk membendung Sosialisme di Dunia Ketiga. Tidaklah mengherankan jika banyak para penganalisa menempatkan gagasan development pada dasarnya merupakan bungkus baru dari kapitalisme.

Bagaimana pikiran development disebar luaskan kedunia ketiga?. Para pakar ilmu sosial pada tahun 1950 an dan 1960 an, memainkan peran diskursive. Mereka yang berafiliasi pada the Center for International Studies di Massachusetts Institute of Technology membantu membangun akademik wacana tentang development. Dalam tahun 1968, para pakar ilmu sosial Amerika terlibat secara mendalam dalam mempengaruhi kebijakan Amerika untuk globalisasi wacana development dan modernisasi. Pakar ilmu sosial yang diminta oleh Truman untuk melakukan "Conference on the implementation of Title IX of the Foreign Assistance Act of 1961" dengan tugas utama melakukan studi bagaimana kebijakan melahirkan the Foreign Assistance Act of 1966, dimana dominasi interpetasi ilmuan liberal terhadap konsep Development. Itulah masa produktif menciptakan pengetahuan dan teori development dan modernisasi. Ekonom Rostow menemukan "Growth theory."nya, dan waktu itu pula McClelland dan Inkeles menemukan teori Modernisasi. Salah satu hasil studi 
mereka bahwa gagasan development dan modernisasi harus menjadi pilar utama bagi kebijaksanaan program bantuan dan politik luar negeri Amerika.

Konsep development dan modernisasi kemudian serta merta dianut oleh berjuta rakyat di Dunia Ketiga yang pada dasarnya merupakan refleksi dari paradigma Barat tentang perubahan sosial. Development, diidentikan dengan gerakan menuju 'higher modernity.'. Konsep ini mempunyai akar sejarah dan intektualitas perubahan sosial yang diasosiasikan dengan revolusi industri di Eropa. Interpretasi konsep development sebagian besar Dunia Ketiga dipahami sebagai 'general improvement in the standard of living'.

Gagasan Development dan modernisasi menjadi program massif. Selain menjadi doktrin politik bantuan luar negeri Amerika baik pada pemerintah Dunia Ketiga maupun LSM, juga serempak hampir di setiap universitas di Barat membuka suatu kajian baru yang dikenal dengan 'Development Studies' sebagai proses mempercepat penyebar serapan kapitalisme dipenjuru dunia. Tidak hanya itu, bahkan team ahli ilmu sosial tersebut mengajukan proposal untuk menggunakan berbagai cara mendeseminasikan ideologi 'development' dan modernisasi dengan target bangsa dunia Ketiga.

Pengetahuan Development yang diproduksi negara Barat dikrimkan ke rakyat Dunia Ketiga bukanlah pengetahuan netral, selain syarat dengan ideologi Barat juga terkandung nafsu untuk mengontrol. Melalui wacana development, dunia pertama menetapkan kontrol pada dunia ketiga, dimana dunia ketiga diberi label 'kekurangan' tentang hal yang dapat dipenuhi oleh technology dan keahlian profesional. Dan hubungan inilah menurut Mueler disebut sebagai hubungan imperialisme (Mueller, 1987). Escobar (1984) menggunakan analisa Foucault tentang wacana terhadap pembangunan. Wacana development selanjutnya tidak memberi legitimasi segala bentuk cara dan pengetahuan 'nonpositivistic' seperti cara pertanian tradisional digusur oleh green revolution serta menghancurkan segala bentuk sosial formasi yang non-capitalistik. Seperti tradisi "gotong Royong" telah diganti oleh hubungan yang kapitalistik. Dan terkahir ide development menghancurkan segala bentuk proses politik yang dikenal doktrin modernisasi politik. Itu semua menujukkan bahwa wacana development merupakan suatu proses pendominasian secara intellektual, politik, ideologi, ekonomi dan budaya. Demikian wacana development tersebut berkembang, dan dimasing masing negara berkembang wacana tersebut lebih dikembangkan secara mendalam lagi hingga sampai dipedesaan termasuk di Indonesia. Sehingga bagi rakyat Indonesia, gagasan pembangunan telah diterima tanpa pertanyaan. Perdebatan hanya dilakukan dalam tingkat cara, metodologi serta teknik pelaksanaan belaka, dan bukan pada level prinsipnya. Itulah mengapa bisa disimpulkan bahwa 'developmentalisme' dewasa ini sudah diyakini oleh sebagain besar birokrat pemerintahan, akademisi, dan bahkan aktivis LSM di Indonesia sebagai satu satunya jalan menuju masyarakat sejahtera.

Lantas persoalannya apa ? Letak masalahnya adalah, apakah ideologi dan teori Development dan modernisasi yang kini menjadi the mainstream teori dan praktek perubahan sosial itu, sejak dalam gagasan dan konsepsi dasarnya terkandung gagasan akan terciptanya dunia yang secara mendasar lebih baik dan lebih adil? Apakah gagasan development' yang diciptakan sebagai bungkus baru 
dari kapitalisme yang diniatkan dalam rangka membendung pengaruh sosialisme itu mampu menghancurkan struktur ekonomi yang eksploitatif; menyingkirkan proses budaya dan pengetahuan yang dominatif, melenyapkan sistim politik yang represif, melindungi lingkungan, serta melenyapkan dominasi terhadap perempuan, sejak dari konsep dasarnya? Inilah persoalan mendasar kita semua.

\section{Tentang Gagasan Devlopment}

Gagasan Devlopment pada awalnya adalah merupakan suatu fenomena luar biasa, dimana sebuah gagasan begitu mendominasi dan mempengaruhi pikiran bangsa - bangsa Dunia Ketiga, bahkan secara global. Gagasan 'development' nyaris menjadi 'agama baru'. Development menjanjikan harapan baru untuk memecahkan masalah masalah kemiskinan dan keterbelakangan bagi berjuta juta rakyat di Dunia Ketiga. Istilah 'development' tersebut, kini telah menyebar dan dipergunakan sebagai visi, teori dan proses yang diyakini oleh rakyat dihampir semua negara, khususnya dunia ketiga, dengan diterjemahkan kedalam bahasa dengan menggunakan kata yang sesuai dengan bahasa lokal dimasing masing negara. Dinegara negara Amerika Latin misalnya, kata ini disamakan dengan kata 'dessarollo'. Bahkan di negara yang belum memiliki bahasa nasional seperti di Filipina misalnya, kata yang dipergunakan untuk melokalkan 'development' adalah dalam tiga bahasa daerah utama, yakni 'pang-unlad' untuk bahasa Tagalok, sedang dalam bahasa Ilongo adalah 'pag-uswag', dan dalam bahasa Ilocano menjadi 'progreso'. Di Indenesia, kata 'development' diterjemahkan dengan 'pembangunan'.

Kata 'pembangunan' menjadi wacana yang dominan di Indonesia erat kaitannya dengan munculnya "pemerintahan orde baru". Selain sebagai semboyan mereka, kata 'pembangunan' juga menjadi nama bagi pemerintahan orde baru, hal itu bisa dilihat bahwa nama kabinet sejak pemerintahan Orde Baru, selalu dikaitkan dengan kata 'pembangunan', meskipun kata 'pembangunan' sesungguhnya telah dikenal dan dipergunakan sejak masa orde lama. Kata pembangunan dalam konteks orde baru, sangat erat kaitannya dengan 'wacana development' yang dikembangkan oleh negara negara Barat.

Uraian berikut mencoba melakukan penyelidikan secara kritis terhadap konsep 'development', yang menjadi sumber dari pemikiran 'pembangunan' di Indoneisa. Oleh karena itu perhatian uraian ini tidaklah mengusahakan tinjauan dari segi bahasa, melainkan mencoba menstudi politik ekonomi dalam permulaan wacana development, dan bagaimana development disebar-serapkan kedunia ketiga, serta hubungannya dengan wacana 'pembangunan' di Indonesia sejak pemerintahan militer Orde baru. 


\section{Tentang Konsep Pembangunan}

Jika dilihat dari pengertian dasarnya, tidak ada suatu konsep dalam ilmu ilmu sosial yang serumit dan tidak jelas seperti kata tersebut. Istilah 'pembangunan' dipakai dalam bermacam macam kontek, dan seringkali dipergunakan dalam konotasi pilitik dan ideologi tertentu. Ada banyak kata yang mempunyai makna dengan kata pembangunan, seperti misalnya perubahan sosial, pertumbuhan, kemajuan, modernisasi. Dari kata kata tersebut hanya istilah perubahan sosial yang memberi makna perubahan kerah lebih positif. Oleh karena makna pembangunan bergantung pada kontek siapa yang menggunakannya dan untuk kepentingan apa, maka uraian mengenai pengertian pembangunan akan dilihat dari kontek sejarah bagaimana istilah tersebut dikembangkan.

Jika dilihat dari konteks sejarahnya mengapa dan bagaimana developmentalisme diciptakan, jelas bahwa gagasan tersebut justru dikembangkan dalam rangka membendung pengaruh dan semangat anti Kapitalisme bagi berjuta juta rakyat di Dunia Ketiga. Gagasan development dimulai tahun 1940an, khususnya pada tanggal 20 Januari 1949, yakni pada saat President Amerika Harry S.Truman mengumumkan kebijakan pemerintahnya, maka istilah development dan "underdevelopment" resmi menjadi bahasa dan doktrim kebijakan luar negeri Amerika Serikat. Selain lebih dimaksud untuk memberi jawaban atas penolakan bangsa Dunia Ketiga yang baru merdeka atas kapitalisme, juga sebagai jawaban ideologi terhadap meningkatnya daya tarik rakyat Dunia Ketiga terhadap keberhasilan Uni Sovyet sebagai kekuatan baru. Oleh karena itu jelas bahwa gagasan development mulanya dilontarkan dalam kerangka 'perang dingin' yakni suatu kebijakan untuk membendung Sosialisme di Dunia Ketiga. Tidaklah mengherankan jika banyak para penganalisa menempatkan bahwa gagasan development pada dasarnya adalah merupakan bungkus baru dari kapitalisme.[2]

\section{Penyebaran Pikiran Development Pada Dunia Ketiga}

Bagaimana pikiran development (Kapitalisme) tersebut disebar luaskan kedunia ketiga?. Para pakar ilmu ilmu sosial pada tahun 1950 an dan 1960 an, memainkan peran diskursive yang penting. Mereka yang berafiliasi pada the Center for International Studies di Massachusetts Institute of Technology (MIT) pada saat itu membantu membangun akademik wacana tentang development.[3] Dalam tahun 1968, para pakar ilmu ilmu sosial Amerika menjadi terlibat secara mendalam dalam mempengaruhi kebijakan Amerika untuk globalisasi wacana tentang development dan modernisasi. Para pakar ilmu- ilmu sosial yang diminta oleh pemerintah Truman untuk 
mengembangkan suatu "Conference on the implementation of Title IX of the Foreign Assistance Act of 1961." dimana tugas utama mereka melakukan studi tentang bagaimana kebijakan untuk melahirkan the Foreign Assistance Act of 1966, dimana dominasi interpetasi ilmuan liberal terhadap konsep Development. (Millikan and Pye: 1968 dan Gendzier,I. 1985: p.69-74)). Itulah masa dimana mereka sangat produktif dalam menciptakan pengetahuan dan teori development dan modernisasi. Ekonom seperti Rostow menemukan "Growth theory."nya, dan waktu itu pula McClelland dan Inkeles menemukan teori Modernisasi mereka. Salah satu hasil penting studi mereka adalah bahwa gagasan developnment dan modernisasi harus menjadi pilar utama bagi kebijaksanaan program bantuan dan politik luar negeri Amerika.[4]

Meskipun teori modernisasi bermacam macam, namun mereka meyakini satu hal yang sama yakni bahwa faktor manusia (bukan struktur dan sistem) menjadi fokus utama perhatian mereka. Pertama, yang menggunakan metafora pertumbuhan yakni tumbuh sebagai organisme. Mereka melihat development sebagai proses evolusi perjalanan dari traditional ke modern. Pikiran ini dapat dijumpai dalam teori pertumbuhan yang sangat terkenal yakni "the five-stage scheme" yang dikembangkan oleh W.W. Rostow (1960). Asumsinya adalah bahwa semua masyarakat termasuk masayarakat Barat pernah mengalami 'tradisional' dan akhirnya menjadi "modern." Sikap manusia tradisional disini dianggap sebagai masalah. Seperti pandangan Rostow dan pengikutnya, development akan berjalan secara hampir otomatis melalui akumulasi modal (tabungan dan investasi) dengan tekanan bantuan dan hutang luar negeri. Dia memfokuskan pada perlunya elite wiraswasta yang menjadi motor proses itu.

Pandangan lain didasarkan studi McClelland, Inkeles and Smith (1961). Berdasar tafsiran McClelland atas Max Weber, jika Etika Protestant menjadi pendorong pertumbuhan di Barat, analog yang sama juga bisa untuk melihat pertumbuhan ekonomi. Apa rahasia pikiran Weber tentang Etika Protestant menurutnya adalah "the need for achievement" (N Ach). Alasan mengapa rakyat Dunia Ketiga terbelakang menurutnya karena rendahnya "Need for Achievement" tersebut. Sekali lagi disini sikap dan budaya manusia yang dianggap sebagai sumber masalah. Dan prototipe dari 'the achieving society' pada dasarnya adalah masyarakat kapitalis.[5]

Konsep development dan modernisasi yang kemudian serta merta dianut oleh berjuta juta rakyat di Dunia Ketiga tersebut pada dasarnya merupakan refleksi dari paradigma Barat tentang perubahan sosial. Development, diidentikan dengan seperti gerakan langkah demi langkah menuju 'higher modernity.' Yang dimaksud modernitas disini merefleksi pada bentuk perkembangan dan kemajuan teknologi dan ekonomi seperti yang dialami oleh negara negara industri. Konsep ini mempunyai akar sejarah dan intektualitas perubahan sosial yang diasosiasikan dengan revolusi industri di Eropa. Interpretasi konsep development disebagian 
besar Dunia Ketiga dipahami melulu sebagai 'general improvement in the standard of living'.

Sebentar saja, gagasan Development dan modernisasi menjadi program massif. Selain menjadi doktrin politik bantuan luar negeri Amerika baik pada pemerintah Dunia Ketiga maupun LSM, juga serempak hampir di setiap universitas di Barat membuka suatu kajian baru yang dikenal dengan 'Development Studies'. Melalui Development Studies di Barat ini, proses penyebar serapan kapitalisme dipenjuru dunia dipercepat, yakni melalui teknokrat, intektual dan bahkan aktivist LSM dari Dunia Ketiga yang menjadi pasar utama program studi tersebut. Escobar (1990) menggambarkan proses ekspansi wacana development melalui penciptaan network kelembagaan (seperti lembaga dana internasional, universitas, lembaga riset, badan perencana pembangunan) demi memfungsikan aparat developmentalisme. Dan begitu terkonsolidasi mereka menentukan apa yang harus dibicarakan, dipikirkan, diidamkan, pendek kata semua diarahkan menuju kearah gagasan developmentalisme dan modernisasi.

Tidak hanya itu, bahkan team ahli ilmu ilmu sosial tersebut mengajukan proposal untuk menggunakan berbagai cara untuk mendeseminasikan ideologi 'development' dan modernisasi tersebut dengan target khusus bangsa dunia Ketiga. Pertama, saran mereka, untuk menggunakan pengaruh Amerika Kebijakan Ekonomi dan Perencanaan. Mereka tahu bahwa bahwa bantuan Amerika selama ini sangat effective dalam mempengaruhi kebijakan dan perencanaan ekonomi. Kedua, untuk mendidik pemimpin dunia ketiga, baik dalam bentuk training, maupun perjalanan observasi ke Amerika Serikat. Strategi ini konon diusulkan berdasar pengalaman peran pemimpin mahasiswa dalam menghancurkan pemerintahan nasionalis Indonesia tahun 1966 (Millikan and Pye :136).[6] Saran ketiga, adalah dengan menggunakan sarana agama. Banyak studi agama bahkan mulaui diarahkan pada peran agama dalam development, sehingga perlunya 'sekularisasi' menjadi bahasa resmi pemimpin agama dunia ketiga. Sedangkan yang terakhir, adalah untuk menggunakan fungsi training dan research dari tenaga universitas Amerika yang bekerja diluar negeri atas biaya USAID. (Millikan and Pye,1968. p:165).

Pengetahuan akan Development yang diproduksi oleh negara Barat dan dikrimkan ke rakyat Dunia Ketiga bukanlah pengetahuan neutral, selain syarat dengan ideologi Barat juga terkandung nafsu untuk mengontrol. Melalui wacana development, dunia pertama menetapkan kontrol mereka pada dunia ketiga, dimana dunia ketiga mula- mula diberi label 'kekurangan'tentang hal hal yang dapat dipenuhi oleh technology dan keahlian profesional. Dan hubungan inilah menurut Mueler disebut sebagai hubungan imperialisme (Mueller, 1987). Escobar (1984) menggunakan analisa Foucault tentang wacana terhadap pembangunan.[7] Wacana development selanjutnya tidak memberi legitimasi segala bentuk cara dan pengetahuan 'non-positivistic' seperti cara pertanian 
tradisional digusur oleh green revolution serta menghancurkan segala bentuk sosial formasi yang non-capitalistik. Seperti tradisi "gotong Royong" di Jawa telah diganti oleh hubungan yang kapitalistik. Dan terkahir ide development menghancurkan segala bentuk proses politik dengan apa yang dikenal doktrin modernisasi politik. Itu semua menujukkan bahwa wacana development merupakan suatu proses pendominasian secara intellektual, politik, ideologi, ekonomi dan budaya.

Invasi kultural, politik, dan ekonomi development selain didukung pemerintah Amerika Serikat juga didukung oleh lembaga lembaga dana internasional seperti bank Dunia dan IMF. Hayter (1985) mencatat adanya konsistensi secara ideologi dari Bank Dunia terhadap ideologi development. (Hayter,1985: 111). 'Development aid' sering dikembangkan dalam rangka menjaga status quo. Mereka mengikat negara berkembang pada ekonomi negara kaya. Bagian terbesar dari apa yang disebut aid biasanya digunakan oleh pemerintah Dunia Ketiga untuk melayani loans Bank Dunia. sebagian yang lain dijatahkan oleh pemberi bantuan dalam rangka melicinkan exports serta medukung kepentingan bisnis mereka sendiri yang mereka tanamkan di Dunia Ketiga (Kruijer,1987. p.116).

\section{Proses Berkembangnya Wacana Development di Indonesia}

Demikian wacana development tersebut berkembang, dan dimasing masing negara berkembang wacana tersebut lebih dikembangkan secara mendalam lagi hingga sampai dipedesaan. Di Indonesia, ideologi developmentalisme yang kemudian diterjemahkan dalam pembangunan tersebut dikembangkan melalui mekanisme kontrol ideologi, sosial dan politik yang canggih. Untuk melindungi ideologi pembangunan tersebut, pemerintah menegakkan berbagai pendekatan seperti: pertama, menegakan 'the floating mass policy', yakni suatu kebijakan yang melarang semua organisasi masa pada tingkat desa. kedua, menggeser sistim pemilihan lurah yang dilakukan secara demokratis, dan menggantikannya dengan penempatan seorang militer sebagai kepala desa. Ketiga, memperkokoh organisasi militer sampai tingkat kecamatan, dan menempatkan seorang militer untuk setiap desa (Babinsa). Keempat, menciptakan KUD sebagai satu satunya Koperasi yang diizinkan opersai ditingkat kecamatan, serta terkahir menciptakan pertauran pemerintah desa sejak tahun 1979, untuk menggantikan tradisi 'rembuk desa' dengan lembaga desa yang dikontrol oleh pemerintah (Sasono,1987).

Pembangunan juga dikembangkan melalui pendidikan, baik formal, mulai dari sekolah dasar hingga perguruan tinggi, maupun non formal seperti dalam kursus- kursus, seminar dan penataran hingga ke khutbah dan pengajian di majlis taklim dan masjid masjid. Program pembangunan dikembangkan dan diselenggarakan baik melalui organisasi besar dalam departemen pemerintah dengan skala besar dan nasional, sampai ditingkat pedesaan yang didukung oleh 
banyak Lembaga Swadaya Masyarakat dengan skala kecil tingkat lokal. Sehingga bagi rakyat Indonesia, gagasan pembangunan telah diterima tanpa pertanyaan. Umumnya perdebatan hanya dilakukan dalam tingkat cara, metodologi serta teknik pelaksananya belaka, dan bukan pada level prinsipnya. Itulah mengapa bisa disimpulkan bahwa 'developmentalisme' dewasa ini sudah diyakini oleh sebagain besar birokrat pemerintahan, akademisi, dan bahkan aktivis LSM di Indonesia sebagai satu satunya jalan menuju masyarakat sejahtera.

\section{Persoalan Mendasar sebagai Penutup}

Lantas persoalannya apa? Letak masalahnya adalah, apakah ideologi dan teori Development dan modernisasi yang kini menjadi the mainstream teori dan praktek perubahan sosial itu, sejak dalam gagasan dan konsepsi dasarnya terkandung gagasan akan terciptanya dunia yang secara mendasar lebih baik dan lebih adil? Apakah gagasan development' yang diciptakan sebagai bungkus baru dari kapitalisme yang diniatkan dalam rangka membendung pengaruh sosialisme itu mampu menghancurkan struktur ekonomi yang eksploitatif; menyingkirkan proses budaya dan pengetahuan yang dominatif, melenyapkan sistim politik yang represif, melindungi lingkungan, serta melenyapkan dominasi terhadap perempuan, sejak dari konsep dasarnya? Inilah persoalan mendasar kita semua. Karena justru untuk menganalisis dan mengevaluasi sebuah teori kita memerlukan kacamata, dan berbeda kaca mata akan menghasilkan penilaian yang berbeda pula. Kacamata-kacamata yang dipakai untuk melihat dan menganalisa perubahan sosial inilah yang sering disebut paradigma perubahan sosial. IIIIII

\section{Daftar Pustaka}

Gendzier, Irene. Managing Political Change: Social Scientists and the Third World Boulder. Colorado: Westview Press. 1985. Juga Douglas Lummis," Development Against Democracy" dalam Jurnal Alternatives Vol.16,no.1.1991.

Gendzier, Irene. $\underline{i b i d}$ (1985)

Walt Whitman Rostow adalah bekas Professor MIT, yang pindah ke Gedung Putih menjadi penasehat Presiden Johnson. Lihat, Gettleman,M.E. and D. Mermelstain. The Great Society Reader. The Failure of American Liberalism. New York: Vintage Book.1967. Uraiannya tentang Growth Theory, lihat: Rostow, W.S. The Stages of Economic Growth: A NonCommunist Manifesto. New York: Cambridge University Press, 1960. Sedangkan uraian Modernisasi lihat: Inkeles, Charles and Smith, 
David. Becoming Modern. Massachusetts: Harvard University Press, 1974. Mc Clelland, David.C. The Achieving Society. New York: D.Van Nostrad. 1961.

Asumsi yang sama juga dianut oleh banyak penganut modernisasi seperti dalam antropologi di Indonesia pikiran Kuncoroningrat, juga dalan paham modernisasi Islam di Indonesia. Keterbelakangan umat Islam, menurut hemat mereka adalah akibat dari 'ada yang salah dalam teologi yang dianut umat Islam. Mereka menuduh teologi tradisional yang fatalistik, sebagai penyebab masalah. Asumsi itu dianut oleh kaum modernist sejak Muhammad Abduh atau Jamaluddin Afgani sampai kelompok pembaharu saat ini seperti Gerakan Muhammadiayah dan Nurcholish Madjid c.s. Lihat: Dr. Harun Nasution, Pembaharuan Dalam Islam, Jakarta; Bulan Bintang, 1978. serta majalah Ulumul Kuran tahun 1993.

The role of US universities and Indonesian technocrats in in the process economic, political and ideological change and Development in Indonesia in the 1960s had been explored by several researchers. See David Ransom "The Berkeley Mafia" in Ramparts, No.9, (1970). See Mortimer, Rex.(ed.). Showcase State; TheIllusion of Indonesia's 'Accelerated Modernization' Sydney: Angus and Robertson. 1973. See also Liddle, William. "Modernizing Indonesian Politics" in William Liddle (ed.). Political Participation in Modern Indonesia. Monograph Series No.19. New Heaven: Yale University Souteast Asian Studies. 1973.

Michel Foucault, apa akhir tahun 1960 dan awal 1970 an memnyumbangkan gagasan kritik dalam pikiran bagaimana makna dikonstruksi. Baginya 'knowledge is not something that can exist apart from power relations'. Karyanya dalam wacanas mempunyai implikasi radikal tidak saja pada sisplin ilmu humaniora, seni dan sastra tapi human semua pengetahuan. Escobar (1978) meminjam analisanya untuk menganalisa hubungan dunia pertama dan ketiga melalui development.

\section{Bahan Bacaan Lainya}

Agustang, A. (1999). INTERAKSI SOSIAL DAN PERUBAHAN STRUKTUR

KOMUNITAS. Universitas Padjadjaran Bandung.

Agustang, A. (2009). SIMBOLIKHAJI: Studi Deskriptif Analitik pada Orang Bugis. Al-Qalam, 15(2), 317-334.

Agustang, A. (2014). LIFE BEHAVIOR OF SOCIETY, FIVE CASES ON FAMILY OF DIABETES MELLITUS PATIENTS IN MAKASSAR. International Journal of Academic Research, 6(1).

Agustang, A. (2018). PERILAKU MEROKOK REMAJA SISWA SMA NEGERI

1 SINJAI UTARA KABUPATEN SINJAI. Jurnal Ilmiah Kesehatan 
Diagnosis, 13(1), 93-99.

Agustang, A. (2021a). Filosofi Research Dalam Upaya Pengembangan Ilmu. OSF Preprints.

Agustang, A. (2021b). Teknologi Partisipasi Metode Fasilitasi Pembuatan Keputusan Partisipatif. OSF Preprints.

Agustang, A., \& Adam, A. (2020). INSTITUTIONAL FAILURES IN THE WORLD OF EDUCATION IN SCHOOLS FOR CHILDREN VICTIMS OF PARENTS. Asian Journal of Social Sciences \& Humanities, 9(2), 18-26.

Agustang, A., \& Indah, A. M. (2021). Andi Asrifan. 2021.“. KONSTRUKSI SOSIAL JANDA TEREKSPLOITASI (STUDI KASUS DI KELURAHAN TETEBATU KECAMATAN PALLANGGA KABUPATEN GOWA)." OSF Preprints. January, 10.

Agustang, A., \& Mustafah, M. Y. (2017). METROSEKSUAL DIKOTA MAKASSAR.

Agustang, A., \& Oruh, S. (2021). KESEJAHTERAAN PSIKOLOGIS (studi Pada Dewasa Madya Yang Belum Menikah Di Kota Makassar).

Agustang, A., Saleh, S., Rasyid, R., \& Agustang, A. T. P. (2019). Pengembangan profesionalisme guru SMP Negeri 1 Duampanua Kabupaten Pinrang melalui pelatihan penulisan karya tulis ilmiah. Seminar Nasional Pengabdian Kepada Masyarakat, 2019(2).

Agustang, A., Suardi, S., Putra, A. D. M., \& Oruh, S. (2021). Pemberdayaan Guru Mata Pelajaran Sosiologi Melalui Literasi Digital Berbasis Quick Response Code di Kecamatan Bissappu Kabupaten Bantaeng. Abdi: Jurnal Pengabdian Dan Pemberdayaan Masyarakat, 3(2), 175-188.

Agustang, A. Y. A., Herman, H., Said, M., \& Agustang, A. (2021). Upaya Guru IPS Dalam Meningkatkan Motivasi Belajar Siswa Pada Masa Covid 19 Di SMP. Phinisi Integration Review, 4(1), 144-149.

Ahriani, A., Agustang, A., Adam, A., \& Upe, A. (2020). The Multiple Roles of Women in Poor.

Akbar, H., Oruh, S., \& Agustang, A. (2021). Indeks Prediktif Kejadian Demam Berdarah Dengue (DBD) Berbasis Perilaku Sosial Masyarakat Di Kabupaten Indramayu. Jurnal Kesehatan, 14(2 SE-), 76-82.

https://doi.org/10.32763/juke.v14i2.289

Al Yakin, A., \& Agustang, A. (2020). SELEBRIFIKASI DAN ELEKTABILITAS; MENAKAR RESPON PUBLIK.

Alamsyah, A., Agustang, A., Adam, A., \& Alim, A. (2021). Partisipasi Teritorial Masyarakat Lingkar Tambang Morosi Kabupaten Konawe. Seminar Nasional LP2M UNM.

Alim, A., Agustang, A., \& Adam, A. (2021). Transformation of Consumption Behavior of the Poor in the Case of Malnutrition: Health Sociology Study 
with Participatory Approach in Makassar City, Indonesia. Open Access Macedonian Journal of Medical Sciences, 9(E), 598-607.

AM, S. A., Agustang, A., Mustadjar, M., \& Tahmir, S. (2020). Mobility and Social Change of the Economy of Indonesian Migrant Workers in Indonesia. Solid State Technology, 63(5), 408-417.

Aminah, S., Agustang, A., Idkhan, A. M., \& Rifdan, R. (2021). KUALITAS PELAYANAN PUBLIK PADA KANTOR PERTANAHAN KABUPATEN PANGKAJENE DAN KEPULAUAN. JISIP (Jurnal Ilmu Sosial Dan Pendidikan), 5(4).

Amran, N. G., \& Agustang, A. (2020). Implementasi Kurikulum 2013 Dalam Peningkatan Kompetensi Psikomotorik Dan Afektif Siswa. Phinisi Integration Review, 3(2), 179-184.

Andini, N. F., \& Agustang, A. (2021). SISTEM PERJODOHAN ANAK DI KECAMATAN MANGGALA KOTA MAKASSAR. Pinisi Journal of Sociology Education Review, 1(2), 192-198.

Andriana, Agustang, A., Idkhan, A. M., \& Hasriadi. (2021). Daya Tanggap Pelayanan Unit Gawat Darurat di Puskesmas Sarjo Kabupaten Pasangkayu . Journal Governance and Politics (JGP), 1(2 SE-Articles). https://ejournal.iyb.ac.id/index.php/jgp/article/view/201

Ardiansyah, A. A., \& Agustang, A. (2018). MAHASISWI BERKELUARGA DI FAKULTAS ILMU SOSIAL UNIVERSITAS NEGERI MAKASSAR. JURNAL SOSIALISASI, 19-23.

Arham, M., \& Agustang, A. (2021). PERUBAHAN MEDIA BERMAIN DAN PERGESERAN GAYA HIDUP ANAK DI LINGKUNGAN BULU KECAMATAN MATTIRO BULU KABUPATEN PINRANG. Pinisi Journal of Sociology Education Review, 1(2), 22-29.

Arifin, L., Agustang, A., \& Idkhan, A. M. (2021). Analysis of the Challenges of Motor Vehicle Tax Revenue at the Technical Service Unit Office Revenue. Jurnal Ad'ministrare, 8(1), 427-434.

Aris, Agustang, A., \& Idkhan, A. M. (2021). Efektifitas Pelayanan Aparatur Sipil Dalam Meningkatkan Pelayanan Publik. Journal Governance and Politics (JGP), 1(2 SE-Articles). https://jurnal.iyb.ac.id/index.php/jgp/article/view/208

Arisal, A., Agustang, A., \& Syukur, M. (2020). Diskriminasi Sosial Anak Penderita Kusta di Kota Makassar. Phinisi Integration Review, 3(2), 297304.

Arpin, Agustang, A., \& Idkhan, A. M. (2021). Pengaruh Penerapan Model Dicovery Learning Terhadap Hasil Belajar Siswa Pada Mata Pelajaran IPA SD Inpres Tamalanrea V Kota Makassar. Journal Governance and Politics (JGP), 1(2 SE-Articles). https://ejournal.iyb.ac.id/index.php/jgp/article/view/204 
Arwin, Agustang, A., Ihsan, A., \& Suhaeb, F. (2015). POVERTY AND MODERNIZATION IN BAJO FISHING COMMUNITY. International Journal of Academic Research, 7(Vol. 7. No. 3. May, 2015).

Asri, A., Kasnawi, T., \& Agustang, A. (2019). Actors' Social Tensions on Traditional Birth Attendants and Midwife Partnerships in Childbirth Assistance (Sociology of Health Study in Bulukumba Regency). IOSR Journal Of Humanities And Social Science (IOSR-JHSS), 24(Issue 1, Ser. 10), 20-27.

Aswan, A., \& Agustang, A. (2017). PERILAKU ANOMI (STUDI PADA SISWA DI SMP NEGERI 21 MAKASSAR). JURNAL SOSIALISASI, 62-66.

Azis, F., Idris, R., \& Agustang, A. (2017). Involution Fisheries: Post-Study Model of National Program in Integrated Movement at Community Fishermen's Village Development Arungkeke, Jeneponto. Mediterranean Journal of Social Sciences, 8(1 SE-Articles), 441.

https://www.richtmann.org/journal/index.php/mjss/article/view/9713

Badwi, A., Agustang, A., \& Adam, A. (2018). Individual Cognitive Dissonance in Society on Condom (A Sociology of Health Study in Makassar City). IOSR Journal Of Humanities And Social Science (IOSR-JHSS), 23(Issue 8, Ver. 7), 14-19.

Badwi, A., Agustang, A., \& Adam, A. (2020). Individual Cognitive Dissonance in Society on Condom (A Sociology of Health Study in Makassar City).

Bastiana, B., Jumadi, J., Herman, H., \& Agustang, A. D. M. P. (2019). Pelatihan penulisan Penelitian Tindakan Kelas bagi guru SMP Negeri 1 Duampanua Kabupaten Pinrang. Seminar Nasional Pengabdian Kepada Masyarakat, 2019(2).

Bebang, M., \& Agustang, A. (2021). THE SOCIAL ACTION OF THE TEACHERS IN HANDLING INDISIPLINARY STUDENTS AT SMP NEGERI 36 MAKASSAR, SOUTH SULAWESI, INDONESIA. 20(5), 5792-5796. https://doi.org/10.17051/ilkonline.2021.05.652

Bebang, M., Agustang, A., \& Samad, S. (2021). THE SOCIAL ACTION OF THE TEACHERS IN HANDLING INDISIPLINARY STUDENTS AT SMP NEGERI 36 MAKASSAR, SOUTH SULAWESI, INDONESIA. Elementary Education Online, 20(5), 5792-5796.

Bintaha, M., Salman, D., Agustang, A., \& Suhaeb, F. W. (2014). THE ROLE OF SOCIAL CAPITAL TOWARD SOME OTHER CAPITALS FOR RURAL ADVANCEMENT. International Journal of Academic Research, 6(5).

Burchanuddin, A., Agustang, A., Adam, A., \& Alim, A. (2021). Cultural Reproduction in the Socio-political Context of Bone District, South Sulawesi, Indonesia.

Daming, M., Agustang, A., Idkhan, A. M., \& Rifdan, R. (2021). IMPLEMENTASI KEBIJAKAN MAKASSAR RECOVER DALAM 
PENANGANAN COVID-19 DI KOTA MAKASSAR. JISIP (Jurnal Ilmu

Sosial Dan Pendidikan), 5(4).

Dirawan, G. D. (2015). FOSTERING COLLABORATION STREET CHILDREN IN MAKASSAR. Man In India, 95(3), 569-576.

Djalante, A., Agustang, A., Tahmir, S., \& Sahabuddin, J. (2018). A Disadvantaged Tribe in Bajoe Village. Bone Regency: A Phenomenological Research on Bajo Tribe's Social Life in Bone Regency, South Sulawesi.

Djamaluddin, M., Agustang, A., Idkhan, A. M., \& Rifdan. (2021). Pengaruh Implementasi Corporate Social Responsibility PT. Vale Terhadap Kesejahteraan Hidup Masyarakat. Journal Governance and Politics (JGP), 1(2 SE-Articles). https://jurnal.iyb.ac.id/index.php/jgp/article/view/200

Edyanto, E., Agustang, A., Idkhan, A. M., \& Rifdan, R. (2021). Implementasi Kebijakan Otonomi Khusus (Otsus) Papua. JISIP (Jurnal Ilmu Sosial Dan Pendidikan), 5(4).

Erni, E., \& Agustang, A. (2021). PENGARUH TEMAN SEBAYA TERHADAP PERILAKU BOLOS DI KALANGAN PESERTA DIDIK SMK HANDAYANI MAKASSAR. Pinisi Journal of Sociology Education Review, 1(1), 97-102.

Firdaus, F. (2017). Permandian Wae Pellae (Konstruksi Fisik Spasial dan Perubahan Masyarakat Sinjai). Equilibrium: Jurnal Pendidikan, 5(1), 15-20.

Haerul, H., Agustang, A., Idhan, A. M., \& Rifdan, R. (2021). Online Learning Challenges in School. Jurnal Office, 7(2), 215-224.

Hairuddin, Agustang, A., Manda, D., \& Jumadi. (2018). Dynamics of Social Behavior of Using Condoms in Brothel at Jalan Nusantara, Makassar City (Sociology of Health and Illness Review). IOSR Journal Of Humanities And Social Science (IOSR-JHSS), 23(Issue 3, Ver. 11), 33-39.

Haniah, S., Agustang, A., \& Samad, S. (2014). SOCIAL ACTION IN THE CLASSROOM: ANALYSIS OF EDUCATIONAL SOCIOLOGY ON INTERACTION BETWEEN TEACHER AND STUDENT IN SMP KARTIKA CHANDRA MAKASSAR. International Journal of Academic Research, 6(4).

har, M., Agustang, A., Adam, A., \& Upe, A. (2021). Online Learning and Distortion of Character Education in the Covid-19 Pandemic Era. Webology, 18(Special Issue 04), 566-580. https://doi.org/10.14704/web/v18si04/web18149

Hariani, H., Oruh, S., \& Mustari, N. (2021). GAMBARAN POLA ASUH ANAK PADA IBU YANG BEKERJA DI KELURAHAN KARANG ANYAR KOTA MAKASSAR. Media Keperawatan: Politeknik Kesehatan Makassar, 12(1), 1-6.

Harman, H., \& Agustang, A. (2020). PERUBAHAN SOSIAL MASYARAKAT PERMANDIAN WAE TUO DESA WAE TUO KECAMATAN KAJUARA 
KABUPATEN BONE. Jurnal Sosialisasi: Jurnal Hasil Pemikiran, Penelitian Dan Pengembangan Keilmuan Sosiologi Pendidikan, 2, 1-7.

Hermansya, H. (2014). Pengaruh kompetensi profesional guru sosiologi Terhadap Hasil Belajar Ssiswa di SMA Negeri 1 Soppeng Riaja Kabupaten Barru. Skripsi. Dibimbing oleh Prof. Dr. Andi Agustang, M. Si dan H. Dr Muhammad syukur, M, Si. Program Studi Pendidikan Sosiologi Fakulta. universitas negeri makassar.

Hikmah, N., \& Agustang, A. (2017). PERAN POST TEST TERHADAP MOTIVASI BELAJAR PADA MATA PELAJARAN SOSIOLOGI SISWA DI SMA NEGERI 11 MAKASSAR. JURNAL SOSIALISASI.

HIKMAH, N., \& AGUSTANG, A. (2016). PERAN POST TEST TERHADAP MOTIVASI BELAJAR SISWA PADA MATA PELAJARAN SOSIOLOGI DI SMA NEGERI 11 MAKASSAR. Universitas Negeri Makassar.

Idrus, I. I., Salman, D., \& Agustang, A. (2021). Commodification of Environmental Discourse in the Process of Producing Space in Bukit Baruga Housing, Makassar. IOP Conference Series: Materials Science and Engineering, 1125(1), 12087.

Irwan, A. A., Adam, A., \& Upe, A. (2021). Community Empowerment Strategy towards a Sustainable Rural Community-based Tourısm Village. Turkish Online Journal of Qualitative Inquiry (TOJQI), 12(5), 2065-2076.

Irwan, I., \& Agustang, A. (2021). Strategi Keberdayaan Masyarakat Menuju Desa Wisata Berbasis Masyarakat Yang Berkelanjutan. Seminar Nasional LP2M $U N M$.

Ismanto, Agustang, A., \& Idkhan, A. M. (2021). Pengaruh Kompensasi Finansial Terhadap Produktivitas Kerja Karyawan Pada PT PLN (PERSERO) Rayon Makassar Barat. Journal Governance and Politics (JGP), 1(2 SE-Articles). https://e-journal.iyb.ac.id/index.php/jgp/article/view/202

Jumadi, Nurlela, Agustang, A., \& Darman. (2020). Social Actions of Galla Actors in the Kaemba Maros Traditional Village Community Sulawesi Selatan. 3rd International Conference on Social Sciences (ICSS 2020), 748-753.

Jumharyanti, J., \& Agustang, A. (2018). REMITANSI TENAGA KERJA INDONESIA PASCA KEPULANGAN DARI LUAR NEGERI (STUDI TKI DI DESA WORO KECAMATAN MADAPANGGA KABUPATEN BIMA NTB). Jurnal Sosialisasi: Jurnal Hasil Pemikiran, Penelitian Dan Pengembangan Keilmuan Sosiologi Pendidikan, 68-73.

Kasnawi, T., \& Agustang, A. (2014). TRADITIONAL ELITE ON MODERN POLITICS AT SOUTH SULAWESI. International Journal of Academic Research, 6(4).

Khaerun, K. (2014). Khaerun. Pengaruh kemampuan Manajerial Kepala Madrasah dan Kompetensi Pedagogik terhadap Kinerja Guru di Madrasah Tsanawiyah Kabupaten Gowa Provinsi Sulawesi Selatan.(Dibimbing oleh 
Andi Agustang dan Jumadi Tangko). universitas negeri makassar.

Kubangun, N., Agustang, A., \& Adam, A. (2020). Subaltern and Network Strategy Towards Fishermen Community in Aru Islands District. 3rd International Conference on Social Sciences (ICSS 2020), 585-588.

Kurniawan, A., \& Agustang, A. (2021). FAKTOR PENGHAMBAT TINGKAT KEDISIPLINAN SISWA DI SMAN 1 BANTAENG. Pinisi Journal of Sociology Education Review, 1(1), 120-126.

LEGIYO, L., Agustang, A., \& Hakim, M. (2018). Relasi Punggawa dan Sawi pada Bagan Perahu (Studi Kasus Nelayandi Pulau Balang Lompo Kabupaten Pangkep). UNIVERSITAS NEGERI MAKASSAR.

Leiwakabessya, J. E. M., Kasnawi, M. T., \& Agustang, A. (2021). The reality of the conflict of customary lands between the land of laha and the air force in ambon city (case study customary land in the land of laha). Turkish Online Journal of Qualitative Inquiry (TOJQI), 12(09), 4797-4804.

Lestari, S. A., \& Agustang, A. (2021). EFEKTIVITAS PEMBELAJARAN ONLINE PADA MATA PELAJARAN SOSIOLOGI DI SMA NEGERI 22 MAKASSAR. Pinisi Journal of Sociology Education Review, 1(2), 48-54.

Mahendra, R., Agustang, A., Idkhan, A. M., \& Rifdan, R. (2021). Analisis Kinerja Aparatur Sipil Negara Dalam Pelayanan Publik. JISIP (Jurnal Ilmu Sosial Dan Pendidikan), 5(4).

Makmur, M. A., Agustang, A., \& Idkhan, A. M. (2021). Tingkat Kepuasan Masyarakat Terhadap Pelayanan Publik (Evaluasi Implementasi Program Beras Sejahtera Di Kota Palopo). Jurnal Sosio Sains, 7(2), 131-138.

Mallappiang, N., Agustang, A., \& Idkhan, A. M. (2021). Keberadaan Humas Dalam Menunjang Tridharma Perguruan Tinggi Universitas Indonesia Timur Makassar. Journal Governance and Politics (JGP), 1(2), 134-148.

Mario, M., Oruh, S., \& Agustang, A. (2021). Pola Relasi: Kontrak Radikalisme Terhadap Perempuan Milenial. Jurnal Sosialisasi: Jurnal Hasil Pemikiran, Penelitian Dan Pengembangan Keilmuan Sosiologi Pendidikan, 8, 72-86.

Masita, M., \& Agustang, A. (2020). Pergeseran Pemaknaan Perayaan Tradisi Saiyyang Pattu'duq di Tinambung Polewali Mandar. Phinisi Integration Review, 3(2), 173-178.

Masni, M., Oruh, S., \& Agustang, A. (2021). Tinjauan Sosiologis Penanganan Kasus Kekerasan Dalam Rumah Tangga Menurut UU PKDRT Oleh Pengadilan Negeri Pangkep. Jurnal Sosialisasi: Jurnal Hasil Pemikiran, Penelitian Dan Pengembangan Keilmuan Sosiologi Pendidikan, 8, 108-117.

Mawarni, I. S., \& Agustang, A. (2021). KONSTRUKSI SOSIAL MASYARAKAT TERHADAP REALITAS SOSIAL TRADISI SI SEMBA'DI ERA GLOBALISASI (Studi penelitian di Daerah Kandeapi Tikala, Toraja Utara). Pinisi Journal of Sociology Education Review, 1(2), 110. 
Mithhar, M., \& Agustang, A. (2021). Distorsi Pendidikan Karakter Siswa Dalam Pendidikan Jarak Jauh Pada Era Pandemi Covid-19 Di Kabupaten Majene, Indonesia. Seminar Nasional LP2M UNM.

Mufidah, N. F., \& Agustang, A. (2020). STUDI SOSIOLOGI PERNIKAHAN MUBARAK DI PONDOK PESANTREN HIDAYATULLAH MAKASSAR. Jurnal Sosialisasi: Jurnal Hasil Pemikiran, Penelitian Dan Pengembangan Keilmuan Sosiologi Pendidikan, 1, 1-8.

Muhammad, S., Agustang, A., \& Samad, S. (2015). SOCIAL MOVEMENT IN A MINING PROJECT: A STUDY OF SOROWAKOAN CONTENTIOUS POLITICS TOWARDS PT VALE INDONESIA, TBK. IN SOROWAKO, SOUTH SULAWESI. International Journal of Academic Research, 7(Issue ID: IJ15V7N3).

Muis, I., Agustang, A., \& Adam, A. (2020). Lansia Miskin: Demografi Sosial, Distribusi Pekerjaan, Masalah Kesehatan \& Perlindungan Sosial.

Mukti, I., Oruh, S., \& Agustang, A. (2021). Efek Pemberitaan Kekerasan Di Media Sosial Terhadap Citra Negatif Kota Makassar. JISIP (Jurnal Ilmu Sosial Dan Pendidikan), 5(4).

Muslimin, A., Idris, R., \& Agustang, A. (2015). CHILDREN AND SOCIAL ENVIRONMENT OF EDUCATION. International Journal of Academic Research, 7.

Mustadjar, M., \& Agustang, A. (2020). Pergeseran Pola Interaksi Sosial (Studi Pada Masyarakat Banggae Kabupaten Majene). Phinisi Integration Review, 3(2), 138-149.

Nasrullah, M., Agustang, A., \& Idhan, A. M. (2021). Utilization of Information Technology at the Mangarabombang District Office. Jurnal Ad'ministrare, 8(1), 339-346.

Nismawati, N., Oruh, S., \& Agustang, A. (2021). Eksistensi Tari Kabasaran Pada Masyarakat Minahasa. Jurnal Ilmiah Mandala Education, 7(4).

Nonci, N., Salman, D., \& Agustang, A. (2014). SILARIANG: STUDY OF THE SOCIAL CONSTRUCTION OF ETHNIC IN MAKASSAR IN GOWA DISTRICT. International Journal of Academic Research, 6(1).

Nur, S., Andi Agustang, \& Arlin Adam. (2020). Uninhabitable Home: Portraits of Poverty in Cities. Indonesian Journal of Social and Environmental Issues (IJSEI), 1(3 SE-), 234-238. https://doi.org/10.47540/ijsei.v1i3.81

Nurbaety, A., Torro, S., \& Agustang, A. (2015). REDUKSI PERAN GOLONGAN BANGSAWAN BUGIS DALAM KEHIDUPAN SOSIAL DI DESA SANREGO KECAMATAN KAHU. FIS.

Nurdin, N., Salman, D., Agustang, A., \& Malago, J. (2021). The Effect of Social Support and Gratitude on Resilient Persons with Disabilities in Makassar City. IOSR Journal of Humanities And Social Science (IOSR-JHSS), 12(5), 14-21. 
Nursafitra, M., Agustang, A., Idkhan, A. M., \& Nurwiwiana. (2021). Pengaruh Disiplin Kerja dan Komitmen Organisasi Terhadap Kinerja Pegawai di Kantor Dinas Kependudukan dan Pencatatan Sipil Kabupaten Enrekang. Journal Governance and Politics (JGP), 1(2 SE-Articles).

https://jurnal.iyb.ac.id/index.php/jgp/article/view/203

Nursinah, Agustang, A., Adam, A., \& Bastiana. (2021). RELAPSE BEHAVIOR OF NAPZA ABUSE AFTER REHABILITATION IN MAKASSAR CITY. PalArch's Journal of Archaeology of Egypt/Egyptology, 18(08), 1845-1854.

Oruh, S. (2021). Analisis faktor Keaktifan Kader dalam Kegiatan Posyandu. Jurnal Ilmiah Kesehatan Sandi Husada, 10(1), 319-325.

Oruh, S., \& Agustang, A. (2019). Pengaruh Pengetahuan Keluarga, Stigma Masyarakat dan Kepatuhan Minum Obat Terhadap Kekambuhan Penyakit Gangguan Jiwa di Kota Makassar. 53(9). https://doi.org/10.1017/CBO9781107415324.004

Oruh, S., \& AGUSTANG, A. (2019). PENGARUH PENGETAHUAN KELUARGA, STIGMA MASYARAKAT DAN KEPATUHAN MINUM OBAT TERHADAP KEKAMBUHAN PENYAKIT GANGGUAN JIWA DI KOTA $M A K A S S A R$.

Oruh, S., Agustang, A., \& Bagu, A. A. (2017). KEJADIAN HEROPNAM GANGGUAN JIWA DAN FAKTOR YANG MEMPENGARUHI PADA RUMAH SAKIT KHUSUS DAERAH DADI PROVINSI SULAWESI SELATAN.

Oruh, S., Agustang, A., \& Bagu, A. A. (2020). KEJADIAN HEROPNAM GANGGUAN JIWA DAN FAKTOR YANG MEMPENGARUHI PADA RUMAH SAKIT KHUSUS DAERAH DADI PROVINSI SULAWESI SELATAN.

Oruh, S., \& Nur, H. (2021). Perilaku Masyarakat Pesisir di Hutan Mangrove Desa Balangdatu Kabupaten Takalar. Phinisi Integration Review, 4(2), 292-300.

Oruh, S., Theresia, M., \& Agustang, A. (2019). KESEJAHTERAAN PSIKOLOGIS. Researchgate.Net.

Pettalongi, A., Idris, R., Kasnawi, T., \& Agustang, A. (2015). PROMOTING SOCIAL VALUES IN BUILDING SOCIAL INTERACTION AMONG INTER-ETHNICAL STUDENTS IN SMA KARUNA DIPA, PALU. International Journal of Academic Research, 7.

Rachim, A., Lolo, T. R. A., \& Agustang, A. (2017). RELATIONS AUTHORITY.

Rahman, B., Agustang, A., \& Samad, S. (2015). HEGEMONIC SOCIAL RELATION, A STUDY OF SOCIOLOGY ON OUTSOURCING PRACTICE. International Journal of Academic Research, 7.

Rahman, N., Agustang, A., Akib, H., \& Tahmir, S. (2015). ANALYSIS OF THE DETERMINANT FACTORS OF IN THE LEGISLATIVE PROCESS OF REGIONAL HOUSE OF PEOPLES'REPRESENTATIVES IN TAKALAR 
REGENCY. International Journal of Academic Research, 7.

RAHMAN, S. (2014). Industri Pabrik dan Masyarakat Lokal di Pinggiran Kota Makassar: Kasus Dua Komunitas Desa Sekitar PT. Kawasan Industri Makassar,(dibimbing oleh HM Idrus Abustam, Andi Agustang dan H. Heri Tahir). universitas negeri makassar.

Rajab, M. A., Oruh, S., \& Agustang, A. (2021). Persepsi Masyarakat Lokal terhadap Ekowisata Mangrove Kuri Caddi Desa Nisombalia Kabupaten Maros. Pepatudzu: Media Pendidikan Dan Sosial Kemasyarakatan, 17(2), $166-172$.

Ramlafatma, R., Oruh, S., \& Agustang, A. (2021). Efektivitas Pendidikan Moral Dalam Pembentukan Karakter Siswa Di TK Islam Terpadu Asa Sumbawa. Jurnal Ilmiah Mandala Education, 7(4).

Rasyid, D., Agustang, A., Syukur, M., Usman, S., \& Marzuki, M. (2021). Social Transformation of Indonesian Older Adults in Suburbs: An Exploratorydescriptive Qualitative Study. Ethno Med, 15((1-2)), 44-52.

Rasyid, R., Agustang, A., Agustang, A. T. P., Bastiana, B., \& Najamuddin, N. (2020). Analisis Faktor Yang Mempengaruhi Status Kemiskinan Rumah Tangga Pada Wilayah Central Bussiness District (CBD) di Kota Makassar. Majalah Geografi Indonesia, 34(1), 43-52.

Reskiawan, M. M. N., \& Agustang, A. (2021). SISTEM SEKOLAH BERASRAMA (BOARDING SCHOOL) DALAM MEMBENTUK KARAKTER DISIPLIN DI MAN 1 KOLAKA. Pinisi Journal of Sociology Education Review, 1(2), 125-133.

Rieuwpassa, S., Agustang, A., \& Adam, A. (2020). Sustainable Peace Development In Ambon (An Analysis Study In Negeri Hila And Dusun Hila Tanah Putih). INTERNATIONAL JOURNAL OF SCIENTIFIC \& TECHNOLOGY RESEARCH, 9(2), 477-480.

Risal, R., Agustang, A., \& Syukur, M. (2021). Peranan Perempuan Tani dalam Meningkatkan Ekonomi Keluarga di Kelurahan Bonto Langkasa Kecamatan Bissappu Kabupaten Bantaeng. Phinisi Integration Review, 4(2), 282-291.

Rongrean, B., Abustan, I., \& Agustang, A. (2015). THE SOCIAL DYNAMICS OF PEDICAB DRIVER TOWARD CLIMATE CHANGES IN MAKASSAR. International Journal of Academic Research, 7.

Rusli, M., Bulkis, S., \& Agustang, A. (2018a). MAKNA PERAN DAN MODAL SOSIAL PEREMPUAN NELAYAN BAJO (Studi Fenomenologi di Pesisir Pantai Soropia Kabupaten Konawe). UNIVERSITAS NEGERI MAKASSAR.

Rusli, M., Bulkis, S., \& Agustang, A. (2018b). Usage of Social Capital in Supporting the Welfare of the Coastal Community. IOSR Journal Of Humanities And Social Science (IOSR-JHSS), 23(Issue 8, Ver. 2), 26-32.

Saeni, R., \& Agustang, A. (2014). INDUSTRIAL FACTORY AND LOCAL 
COMMUNITIES ON THE MARGINAL CITY OF MAKASSAR.

International Journal of Academic Research, 6(4).

Safar, M., Agustang, A., \& Adam, A. (2017). PSEUDO AKTOR POLITIK (Studi Genealogi Kekuasaan di Sulawesi Tenggara Indonesia). Pascasarjana.

Sahabuddin, A., Agustang, A., \& Idkhan, A. M. (2021). Fungsi Leadership dalam Peningkatan Pelayanan Publik di Kantor Kecamatan Makassar. Journal Governance and Politics (JGP), 1(2 SE-Articles). https://jurnal.iyb.ac.id/index.php/jgp/article/view/207

Sahabuddin, E., Agustang, A., Manda, D., \& Oruh, S. (2020). Partisipasi Sosial Dalam Pemenuhan Activity Daily Living (Adl) Orang Dengan Gangguan Jiwa Di Kota Makassar. Phinisi Integration Review, 3(2).

Salmah, A. U., Idris, R., Agustang, A., \& Maidin, A. (2013). Socio-Cultural Transformation of Early Detection on Breast Cancer Suspect in Wahidin iSudirohusodo Hospital, Makassar Indonesia.

Samanlangi, A. I., Agustang, A., Adam, A., \& Alim, A. (2021). Disconnectivity Social of Conflict in the Circle of Iron Ore Mine in Bone Regency, South Sulawesi, Indonesia. International Journal of Criminology and Sociology, 10, 963-973.

Sanusi, D., Agustang, A., \& Idkhan, A. M. (2021). Pengembangan Sumber Daya Manusia Dalam Meningkatkan Pelayanan Akademik Di Universitas Puangrimaggalatung Sengkang . Journal Governance and Politics (JGP), 1(2 SE-Articles). https://jurnal.iyb.ac.id/index.php/jgp/article/view/205

Sapulette, A. A., Agustang, A., \& Syukur, M. (2018). Actor Construction in the Frame of Diversity to Achieve Social Harmony in the Life of Tamilouw Village Society Seram Island-Maluku. IOSR Journal Of Humanities And Social Science (IOSR-JHSS), 23(Issue 2, Ver. 4), 54-60.

Sari, R. P., \& Agustang, A. (2021). PERAN GANDA IBU RUMAH TANGGA (STUDI KASUS PADA TUKANG CUCI MOBIL/MOTOR). Pinisi Journal of Sociology Education Review, 1(2), 106-113.

Suardi, Agustang, A., \& Jumadi. (2020). A., \& Jumadi.(2020b). The Symbolic Violence Towards Private School Students Through The Frame Stereotype In Bantaeng District Of Indonesia. The International Conference on Innovations in Social Sciences and Education, 578-588.

Suardi, Agustang, A., \& Jumadi. (2021a). DOMINATION OF THE POWER OF QUALITY AND QUANTITY OF STATE SCHOOL EDUCATION AGAINST PRIVATE SCHOOLS AS FACTORS CAUSING SYMBOLIC VIOLENCE OF STUDENTS IN BANTAENG DISTRICT. PROCEEDING 1st INTERNATIONAL CONFERENCE (On Health, Education, and Computer Science Technology), 1(pertama), 246-259.

Suardi, S., Agustang, A., \& Jumadi, J. (2021b). Dominasi Sekolah Negeri 
Terhadap Sekolah Swasta Sebagai Penyebab Kekerasan Simbolik Terhadap Siswa Sekolah Swasta. Jurnal Ilmiah Muqoddimah: Jurnal Ilmu Sosial, Politik Dan Hummanioramaniora, 5(2).

Sulaiman, U., Idris, R., Ardi, M., \& Agustang, A. (2014). The Pattern of Cooperation and Poorness: A Seaweed Farming Community in Indonesia. International Journal of Academic Research, 6(5), 239-242.

Sumai ${ }^{1}$, S., Agustang, A., Adam, A., \& Obie, M. (2020). Resilience in Children of Drug Abuse Families: A Case in Pattingalloang, Makassar City, Indonesia.

Sumitro, S., Oruh, S., \& Agustang, A. (2021). Eksistensi Nilai Sosial Budaya Ndeu Paki Oi Mbaru Pada Masyarakat Donggo Kabupaten Bima. Jurnal Ilmiah Mandala Education, 7(4).

Suparman, Oruh, S., \& Agustang, A. (2021). Dinamika Sosial Kelompok Tani (Studi Kasus Petani Bawang Merah Desa perangian Kecamatan Baraka Kabupaten Enrekang). JIIP-Jurnal Ilmiah Ilmu Pendidikan, 4(6), 406-414.

Sutrisno, S., \& Agustang, A. (2018). Peranan Pengawas Sekolah Terhadap Pelaksanaan Kurikulum 2013 Di SMA Negeri 17 Makassar. Jurnal Sosialisasi: Jurnal Hasil Pemikiran, Penelitian Dan Pengembangan Keilmuan Sosiologi Pendidikan, 100-105.

Syaharuddin, S., Agustang, A., Idkhan, A. M., \& Rifdan, R. (2021). STRATEGI DINAS SOSIAL DALAM PENANGANAN ANAK JALANAN DI KOTA MAKASSAR. JISIP (Jurnal Ilmu Sosial Dan Pendidikan), 5(4).

Syamsul, A. (2014). Remaja penjajah seks komersial kota Makassar. Skripsi Sosiologi, Fakultas Ilmu Sosial, Universitas Negeri Makassar, yang di bimbing oleh. Firdaus W. Suhaeb sebagai pembimbing satu dan Andi Agustang sebagai pembimbing dua. universitas negeri makassar.

Syamsul, B., Idrus, A., Jumadi, S., \& Edwar, P. (2014). “A'PA ALLIRI”: THE SOCIAL FUNCTION OF LOCAL INSTITUTION AT MATAJANG SOCIETY. INTERNATIONAL JOURNAL of ACADEMIC RESEARCH, 6(6), $121-125$.

Syukurman, S., Agustang, A., \& Adam, A. (2020). Peluang dan Tantangan Lembaga Pendidikan Islam (Ditinjau dari Sosiologi Agama di Desa Doridungga). EDU SOCIATA (Jurnal Pendidikan Sosiologi), 3(2), 71-87.

Thamrin, H., Agustang, A., Adam, A., \& Alim, A. (2021). Disrupsi Modal Sosial Stunting di Sulawesi Selatan, Indonesia (Studi Kasus Pada Keluarga 1000 HPK di Kabupaten Bone dan Enrekang). Seminar Nasional LP2M UNM.

Thamrin, M., Agustang, A., Adam, A., \& Alim, A. (2021). Disruption of Stunting Social Capital in South Sulawesi, Indonesia (Case Study on 1000FDL Families in Bone and Enrekang Districts). Indian Journal of Public Health Research \& Development, 12(2).

Tinri, M. D. N. (2018). Hotels and Restaurant Tax Revenues Management. 
Triono, T., Agustang, A., Idkhan, A. M., \& Rifdan, R. (2021). Motivasi Kerja Pegawai Dalam Pelayanan Publik. JISIP (Jurnal Ilmu Sosial Dan Pendidikan), 5(4).

Ufie, A., Oruh, S., \& Agustang, A. (2021). Maintaining Social Harmony Through Historical Learning Based on Local Wisdom of Indigenous Peoples in Maluku. Historia: Jurnal Pendidik Dan Peneliti Sejarah, 5(1), 31-40.

UMAR, S. (2014). Pola Kerjasama dan Ketidaksejahteraan Komunitas Petani Rumput Laut di Kecamatan Ujung Loe Kabupaten Bulukumba (Dibimbing oleh Promotor Rabihatun Idris serta Kopromotor Muhammad Ardi dan Andi Agustang). universitas negeri makassar.

Umasangaji, N. K., Agustang, A., Adam, A., \& Alim, A. (2021). Dampak Pandemi Covid-19 dan Pembelajaran Daring di Kampung Atas Air Balikpapan. Seminar Nasional LP2M UNM.

Urbach, N., \& Agustang, A. (2019). PREFERENSI ORANG TUA DALAM MENYEKOLAHKAN ANAKNYA DI DESA AMOLA KECAMATAN BINUANG KABUPATEN POLEWALI. JURNAL SOSIALISASI, 89-94.

Usman, A., Agustang, A., \& Idkhan, A. M. (2021). Penerapan Pelayanan Prima di Rumah Sakit Paru BBPM Makassar. Journal Governance and Politics (JGP), 1(2 SE-Articles). https://jurnal.iyb.ac.id/index.php/jgp/article/view/206

Wardah, S., Salman, D., Agustang, A., \& Fahmid, I. M. (2017). The Contestation of Organic and Non-Organic Agricultural Knowledge in Sustainable Agriculture. Mediterranean Journal of Social Sciences, 8(2 SE-Articles), 245. https://www.richtmann.org/journal/index.php/mjss/article/view/9883

Wardiani, I., \& Agustang, A. (2018). Dampak Pekerjaan Orang Tua Pengrajin Emas Terhadap Pendidikan Anak di Kelurahan Borong Kecamatan Manggala Kota Makassar. UNIVERSITAS NEGERI MAKASSAR.

Wihdania, W., \& Agustang, A. (2020). Pernikahan Tolotang Di Kelurahan Amparita Kecamatan Tellu Limpoe Kabupaten Sidenreng Rappang. Phinisi Integration Review, 3(2), 165-172.

WULAN, S. (2014). Peranan Media Pembelajaran Dalam Meningkatkan Motivasi Belajar Sosiologi Pada Siswa SMA PGRI Galesong. Skripsi. Dibimbing oleh Andi Agustang dan Hj. Musdaliah Mustadjar Program Studi Pendidikan Sosiologi. Fakultas Ilmu Sosial, Universitas Negeri Makassar. universitas negeri makassar.

Yakobus, I. K., Kasnawi, T., Agustang, A., \& Gani, H. A. (2019). Hybridization of the Poso Conflict Resolution Discourse.

Yudhar, A. N., Agustang, A., \& Sahabuddin, J. (2021). Habituation of character values in junior high school students. Cypriot Journal of Educational Sciences, 16(2), 659-668.

Yunita, I., \& Agustang, A. (2021). Ketidakmerataan Bantuan Langsung Tunai 
Dimasa Pandemi Covid-19 Pada Masyarakat Kurang Mampu di Desa Carawali Kabupaten Sidrap. Pinisi Journal of Sociology Education Review, 1(2), 181-191.

Yusmuliadi, Y., \& Agustang, A. (2021). PERANAN OSIS DALAM MEMBENTUK KARAKTER PEDULI SOSIAL SISWA DI SMA NEGERI 3 BARRU. Pinisi Journal of Sociology Education Review, 1(1), 44-53.

Yusuf, M., Agustang, A., Idkhan, A. M., \& Rifdan, R. (2021). Transformasi Lembaga Koperasi Di Era Industri 4.0. JISIP (Jurnal Ilmu Sosial Dan Pendidikan), 5(4). 